\title{
Is Drinking Water Sources Safe for Drink? A Multicenter Assessment of Fecal Contamination of Drinking Water Sources in Tigray Region, Ethiopia
}

Goyitom Gebremedhn ( $\sim$ ggoyitom@yahoo.com )

Tigray Health Research Institute https://orcid.org/0000-0001-7244-2172

Abera Aregawi Berhe

Tigray Health Research Institute

Abraham Aregay Desta

Tigray Health Research Institute

Lemlem Legesse

Tigray Health Research Institute

Research article

Keywords: Total Coli forms; Fecal Coli forms; water sources; Type of water sources

Posted Date: May 3rd, 2019

DOI: https://doi.org/10.21203/rs.2.9449/v1

License: (c) (i) This work is licensed under a Creative Commons Attribution 4.0 International License.

Read Full License 


\section{Abstract}

Background Fecal contamination of drinking water sources is the main cause of diarrhea with estimated incidence of 4.6 billion episodes and 2.2 million deaths every year. Methods A total of 145 water samples of different source type were collected from different areas in Tigray region from August 2018 to January 2019. The water samples from each site were selected purposively which involved sampling of water sources with the highest number of users and functionality status during the study period. Most Probable Number (MPN) protocol was used for the bacteriological analysis of the samples. Results A total of 145 water samples were collected from six zones in Tigray region, Ethiopia from August 2018 to January 2019. The study indicated that $63(43.5 \%)$ of the water samples were detected to have fecal coliform which is E.coli. In Mekelle city, which is the capital city of Tigray region, three in five $34(60.7 \%)$ of the collected samples were confirmed to have fecal coliform. Water samples from health facilities were 9.48 times [AOR=9.48, 95\% Cl: $(1.59,56.18)]$ more likely to have fecal coliform. Water samples from wells were 10.23 times [AOR=10.23, 95\% Cl: $(2.74,38.26)]$ more likely to have fecal coliform than water samples from Tap/Pipe. Similarly, water samples from hand pumps were 22.28 times [AOR=22.28, 95\% Cl: $(1.26,393.7)$ ] more likely to have fecal coliform than water samples from Tap/Pipe. Water samples reported to be not chlorinated were 3.51 times [AOR=3.51, 95\% Cl: $(1.35,9.13)]$ more likely to have fecal coliform than water samples from chlorinated sources. Conclusion In this study all water source, including the chlorinated drinking water sources, were found highly contaminated with fecal origin bacteria. This may be mainly due to constructional defects, poor sanitation inspection, poor maintenance, intermittent water supply and irregular chlorination.

\section{Background}

Human and animal feces, if not disposed properly, is the main source of microbial contamination of drinking water, which is a great risk to public health $[1,2]$, especially among young children, who have the highest diarrhea rates worldwide [3]. Diarrhea, which is mainly water-related disease, has an estimated annual incidence of 4.6 billion episodes and causes 2.2 million deaths every year [4]. The problem is more serious in rural areas where the majorities of the people do not have access to potable water and therefore, depend on well, stream and river water for domestic use [5].

Water, sanitation, and hygiene are essential for the development and health of human beings. Although the World Health Organization/United Nations Children's Fund (WHO/UNICEF) declared that the world had met the drinking water target in 2010 , they cautioned that the number of people using safe water had been overestimated [6]. In 2015, the WHO/UNICEF Joint Monitoring Program for water supply and sanitation estimates that 663 million people lacked improved drinking water sources and 2.4 billion lacked improved sanitation facilities [7]. In 2017, as of the WHO/UNICEF report, about 28 in 100 people lack access to sufficient and quality drinking water globally [8]. Unsafe and insufficient quantity of drinking water, inadequate sanitation, and unimproved hygiene account for $7 \%$ of the global burden of disease and $19 \%$ of child mortality worldwide $[9,10]$. 
The specific targets of improved access to drinking water supply and basic sanitation for the Millennium Development Goals (MDGs) from 2000-2015 had a great achievement, except for the sanitation coverage $[7,9-10]$. The lack of reliable access to safe and sustainable water, sanitation and hygiene infrastructure, in conjunction with related hygiene and sanitation behaviors, remains a major public health problem, particularly in low and middle income countries [11-14]. Ethiopia met the Millennium Development target of providing drinking water from improved sources [7], but still the safe drinking water access is one of the lowest among the sub-Saharan countries [15].

The group of coliforms which further subdivided into total and fecal coliforms while total includes both soil intermediates and fecal forms, fecal coliforms confines to those from fecal origin, used as standard microbial indicators of water quality since 1920 [16]. The fecal coliforms include Escherichia Coli, Klebsiella, and Enterobacter inhabit the intestinal tract of warm blooded animals [17].

The aim of this study was to assess the fecal contamination of different drinking water sources from different areas in Tigray region. This study will open the entry for further studies on the analysis of water, sanitation, and hygiene (WASH) practice and behavior in the region as there is no published study yet.

\section{Methods}

A total of 145 water samples of different source type were collected from different areas in Tigray region from August 2018 to January 2019. The samples were collected from six zones of Tigray Region.

The water samples from each site were selected purposively which involved sampling of water sources with the highest number of users and functionality status during the study period.

Water samples were collected aseptically from each sampling site in sterile glass bottles and transported to laboratory in ice box at 2-8 $0 \mathrm{c}$ and analyzed within 6 hours of sample collection. For the chlorinated water samples, about $2.5 \mathrm{ml}$ sodium thiosulphate was added into each sampling bottle to stop the chlorination process during transportation. The microbial analysis of the water samples were done by trained microbiologists.

Most Probable Number (MPN) protocol was used to analyze the Total Coli forms (TTCs) in the presumptive test using Mac Conkey broth (Purple) which demonstrated by acid formation indicated by a yellow coloration of the broth, and gas formation indicated by an amount of gas at least sufficient to fill the concavity at the top of the Durham tube. Color change of the broth from purple to yellow is due to fermentation of the lactose and lowering of the $\mathrm{PH}$ during lactose fermentation which is indicated by the Bromocresol purple indicator.

Nine sets of test tubes containing Mac Conkey broth required for each sample, each test tube contained $10 \mathrm{ml}$ broth and inoculated with the water sample in a sequential order of $10 \mathrm{ml}$ in three of each $2 \mathrm{x}$ fermentation broth, $1 \mathrm{ml}$ in three of each $1 \mathrm{x}$ fermentation broth and lastly $0.1 \mathrm{ml}$ in three of each $10 \mathrm{ml} 1 \mathrm{X}$ fermentation broth. All the test tubes were incorporated with Durham tubes for detection of gas formed 
by the coliform bacteria. Test tubes were incubated with half circled screw caps at $370 \mathrm{C}$ for 48 hours [18]. This procedure was followed for all of the 145 samples individually. Positive samples with the production of acid and gas in the Mac Conkey broth were selected for the confirmed test procedures to detect the indicator bacteria of fecal origin Escherichia coli. The confirmed test for the fecal origin $\mathrm{E}$. coli is performed by transferring a loopful of each positive suspension from the Mac Conkey broth to a tube of EC broth [19]. The inoculated EC broth is then incubated at $44.5^{\circ} \mathrm{C}$ for $24 \pm 2$ hours to examine gas production. Negative tubes reincubated and examined again at $48 \pm 2$ hours. The results of this test were used to calculate fecal coliform MPN.

To perform the completed test for E. coli, gently agitate each gassing EC tube, remove a loopful of broth and streak for isolation on a Levine's eosin-methylene blue (L-EMB) agar plate and incubate for 18-24 $\mathrm{h}$ at $35-37^{\circ} \mathrm{C}$. Examine plates for dark centered and flat, with or without green metallic sheen. The presence of green metallic sheen in L-EMB confirms the presence of the fecal indicator bacteria E. coli [18].

\section{Data Processing and Analysis}

The collected data were entered and cleaned in Microsoft excel sheet, and was exported to STATA software Version 14 for analysis. Descriptive analysis of the variables was conducted using frequencies and percentages by making all variables categorical. The presence of an association between the fecal contamination and the independent variables was tested using cross tabulation with chi-square test at Pvalue $\leq 0.05$ significance level, and variables which show statistically significant associations was analyzed using binary logistic regression making fecal contamination $\mathrm{No}=0, \mathrm{Yes}=1$. Our primary outcome of interest was the presence of fecal contamination which was coded "yes" if at least 1 CFU of E. coli was detected in $100 \mathrm{~mL}$ water sample tested. This outcome was chosen as absence of E. coli in $100 \mathrm{~mL}$ of drinking water, which is the indicator for bacteriological quality of safely managed water as targeted in SDG. The independent variables of interest were the zone of sample, source of samples, type of source, season of sample collection(rainy and non-rainy), the presence of chlorine, the presence of fecal coliform, the presence of total coliform, Setting of the sample collected and amount of present total coliform count. In the multivariable logistic regression analysis, stepwise regression method was used to develop the model. The presence of significant interaction terms, influential outliers and multi-collinearity between independent variables was checked. Ethical clearance was obtained from Tigrai health research institute institutional review team. In addition, scientific honesty was made by citing all authors of books and journals used, and acknowledging individuals and organizations contributed for the successful completion of this work.

\section{Results}

A total of 145 water samples were collected from six zones in Tigray region, Ethiopia from August 2018 to January 2019. The contribution of the zones ranges from $9 \%$ in Southeastern to $38.6 \%$ in Mekelle. Two in five $61(42.1 \%)$ of the water samples were collected from towns, and $55(37.9 \%)$ were tap water sources. 
The study indicated that $63(43.5 \%)$ of the water samples were detected to have fecal coliform, which is E.coli (Table 1).

Table 1: General characteristics of the water sample sources collected from six zones in Tigray Region, Ethiopia, from August 2018 to January 2019 


\begin{tabular}{|c|c|c|}
\hline Characteristic & Category & $\mathbf{N}(\%)$ \\
\hline \multirow[t]{6}{*}{ Zone of sample } & Central & $28(19.3 \%)$ \\
\hline & Eastern & $16(11.0 \%)$ \\
\hline & Mekele & $56(38.6 \%)$ \\
\hline & North West & $14(9.7 \%)$ \\
\hline & South & $18(12.4 \%)$ \\
\hline & South East & $13(9.0 \%)$ \\
\hline \multirow[t]{3}{*}{ Setting of the sample collected } & Towns & $61(42.1 \%)$ \\
\hline & Major City (Mekelle) & $56(38.6 \%)$ \\
\hline & Rural & $28(19.3 \%)$ \\
\hline \multirow[t]{3}{*}{ Facility Type } & Public water source & $76(52.4 \%)$ \\
\hline & Health Facility & $37(25.5 \%)$ \\
\hline & Organizations & $32(22.1 \%)$ \\
\hline \multirow[t]{5}{*}{ Type of source } & Tap/Pipe & $55(37.9 \%)$ \\
\hline & Well & $45(31.0 \%)$ \\
\hline & Reservoir & $24(16.6)$ \\
\hline & Spring & $15(10.3 \%)$ \\
\hline & Hand Pump & $6(4.1 \%)$ \\
\hline \multirow[t]{2}{*}{ Season of sample collection } & Rainy & $56(38.6 \%)$ \\
\hline & Non Rainy & $89(61.4 \%)$ \\
\hline \multirow[t]{2}{*}{ Presence of Chlorine } & Yes & $91(62.8 \%)$ \\
\hline & No & $54(37.2 \%)$ \\
\hline \multirow[t]{2}{*}{ Presence of Total Coliform } & Yes & $88(60.7 \%)$ \\
\hline & No & $57(39.3 \%)$ \\
\hline \multirow[t]{2}{*}{ Presence of Fecal Coliform } & Yes & $63(43.5 \%)$ \\
\hline & No & $82(56.6 \%)$ \\
\hline \multirow[t]{4}{*}{ Total coliform count } & 0 & $57(39.3 \%)$ \\
\hline & $1-200$ & $55(37.9 \%)$ \\
\hline & $>200$ & $33(22.8 \%)$ \\
\hline & e $6 / 15$ & \\
\hline
\end{tabular}


In Mekelle city, which is the capital of the region, three in five $34(60.7 \%)$ of the collected samples were confirmed to have fecal coliform. Zone, setting/vicinity and facility of the water sample collected, type of source, season of sample collection, reported water chlorination, and coliform count were the factors significantly associated with the presence of fecal coliform in the water samples.

Table 2: Association of the drinking water sample characteristics with presence of Fecal Coliform for the water sample sources collected from six zones in Tigray Region, Ethiopia, from August 2018 to January 2019 
Characteristic

\begin{tabular}{|c|c|c|c|c|}
\hline & & Yes & No & \\
\hline \multirow[t]{6}{*}{ Zone of sample } & Mekelle & $34(60.7 \%)$ & $22(39.3 \%)$ & $0.001^{\star}$ \\
\hline & Central & $15(53.6 \%)$ & $13(46.4 \%)$ & \\
\hline & South & $3(16.7 \%)$ & $15(83.3 \%)$ & \\
\hline & Eastern & $3(18.8 \%)$ & $13(81.2 \%)$ & \\
\hline & North West & $5(35.7 \%)$ & $9(64.3 \%)$ & \\
\hline & South East & $3(23.1 \%)$ & $10(76.9 \%)$ & \\
\hline \multirow{3}{*}{$\begin{array}{l}\text { Setting of the sample } \\
\text { collected }\end{array}$} & Towns & $18(29.5 \%)$ & $43(70.5 \%)$ & $0.003^{* *}$ \\
\hline & $\begin{array}{l}\text { Major City } \\
\text { (Mekelle) }\end{array}$ & $34(60.7 \%)$ & $22(39.3 \%)$ & \\
\hline & Rural & $11(39.3 \%)$ & $17(60.7 \%)$ & \\
\hline \multirow[t]{3}{*}{ Facility type } & Public source & $43(56.6 \%)$ & $33(43.4 \%)$ & $0.000 * *$ \\
\hline & Health Facility & $15(40.5 \%)$ & $22(59.5 \%)$ & \\
\hline & Organizations & $5(15.6 \%)$ & $27(84.4 \%)$ & \\
\hline \multirow[t]{5}{*}{ Type of source } & Tap/Pipe & 13(23.6\%) & $42(76.4 \%)$ & $0.000 * *$ \\
\hline & Well & $31(68.9 \%)$ & 14(31.1\%) & \\
\hline & Reservoir & $6(25.0 \%)$ & $18(75.0 \%)$ & \\
\hline & Spring & $8(53.3 \%)$ & $7(46.7 \%)$ & \\
\hline & Hand Pump & $5(83.3 \%)$ & $1(16.7 \%)$ & \\
\hline \multirow{2}{*}{$\begin{array}{l}\text { Season of sample } \\
\text { collection }\end{array}$} & Rainy & $35(62.5 \%)$ & $21(37.5 \%)$ & $0.000^{\star *}$ \\
\hline & Non Rainy & $28(31.5 \%)$ & $61(68.5 \%)$ & \\
\hline \multirow[t]{2}{*}{ Presence of Chlorine } & Yes & $31(34.1 \%)$ & $60(65.9 \%)$ & $0.003^{* *}$ \\
\hline & No & $32(59.3 \%)$ & $22(40.7 \%)$ & \\
\hline \multirow[t]{2}{*}{ Presence of Total Coliform } & Yes & $62(70.4 \%)$ & $26(29.5 \%)$ & $0.000 * *$ \\
\hline & No & $1(1.8 \%)$ & $56(98.2 \%)$ & \\
\hline \multirow[t]{3}{*}{ Total coliform count } & 0 & $1(1.7 \%)$ & $56(98.3 \%)$ & $0.000 * *$ \\
\hline & $1-200$ & $32(58.2 \%)$ & $23(41.8 \%)$ & \\
\hline & \multicolumn{2}{|c|}{ Page 8/15 } & & \\
\hline
\end{tabular}

Presence of Fecal Coliform

P-value

Category

Category

Yes 
Factors associated with the presence of fecal coliforms were analyzed and water samples from the central zone were 38 times [AOR=38, 95\% Cl: $(2.43,595.54)]$ more likely to have fecal coliform than Water samples from Mekelle controlling for the other confounders. Compared with water samples from public sources, water samples from health facilities were 9.48 times [AOR=9.48, 95\% Cl: $(1.59,56.18)]$ more likely to have fecal coliform. Water samples from the towns were $98 \%$ [AOR=0.02, $95 \% \mathrm{Cl}:(0.00,0.35)]$ less likely to have fecal coliform than water samples from major city or Mekelle. Water samples from wells were 10.23 times [AOR=10.23, 95\% $\mathrm{Cl}:(2.74,38.26)]$ more likely to have fecal coliform than water samples from Tap/Pipe. Similarly, water samples from hand pumps were 22.28 times [AOR=22.28, 95\% Cl: $(1.26$, 393.7)] more likely to have fecal coliform than water samples from Tap/Pipe. Water samples reported to be not chlorinated were 3.51 times [AOR=3.51, 95\% Cl: $(1.35,9.13)$ ] more likely to have fecal coliform than water samples from chlorinated sources (Table 3 ).

Table 3: Factors associated with presence of fecal Coliform for the water sample sources collected from six zones in Tigray Region, Ethiopia, from August 2018 to January 2019 


\section{Characteristic}

Category

\section{Presence of Fecal \\ Coliform}

\begin{tabular}{|c|c|c|c|}
\hline & & COR $(95 \% \mathrm{Cl})$ & AOR (95\% Cl) \\
\hline \multirow[t]{6}{*}{ Zone of sample } & Mekelle & 1 & 1 \\
\hline & Central & $0.75(0.29,1.86)$ & $38.02(2.43,595.54)^{\star}$ \\
\hline & South & $0.13(0.03,0.49)^{\star}$ & $2.80(0.22,35.16)$ \\
\hline & Eastern & $0.15(0.04,0.58)^{\star}$ & $4.80(0.29,77.95)$ \\
\hline & North West & $0.36(0.11,1.21)$ & $2.18(0.15,31.01)$ \\
\hline & South East & $0.19(0.05,0.78)^{\star}$ & - \\
\hline \multirow[t]{3}{*}{ Setting of the sample } & $\begin{array}{l}\text { Major City } \\
\text { (Mekelle) }\end{array}$ & 1 & 1 \\
\hline & Towns & $0.27(0.12,0.58)^{\star}$ & $0.02(0.00,0.35)^{\star}$ \\
\hline & Rural & $0.42(0.16,1.05)$ & $1.00(0.16,6.24)$ \\
\hline \multirow[t]{3}{*}{ Facility type } & Public source & 1 & 1 \\
\hline & Health Facility & $0.52(0.23,1.16)$ & $9.48(1.59,56.18) \star$ \\
\hline & Organizations & $0.14(0.05,0.41)^{\star}$ & $1.86(0.28,12.22)$ \\
\hline \multirow[t]{5}{*}{ Type of water source } & Tap/Pipe & 1 & 1 \\
\hline & Reservoir & $1.07(0.35,3.28)$ & $0.71(0.16,3.03)$ \\
\hline & Spring & $3.69(1.12,12.13) \star$ & $4.73(0.87,25.74)$ \\
\hline & Well & $7.15(2.95,17.35) \star$ & $10.23(2.74,38.26) \star$ \\
\hline & Hand Pump & $16.15(1.73,151.0) *$ & $22.28(1.26,393.66)^{\star}$ \\
\hline \multirow{2}{*}{$\begin{array}{l}\text { Season of sample } \\
\text { collection }\end{array}$} & Non rainy & 1 & 1 \\
\hline & Rainy & $3.63(1.79,7.33)^{\star}$ & $1.60(0.57,4.50)$ \\
\hline \multirow[t]{2}{*}{ Presence of Chlorine } & Yes & 1 & 1 \\
\hline & No & $2.81(1.41,5.64)^{\star}$ & $3.51(1.35,9.13)^{\star}$ \\
\hline
\end{tabular}

\section{Discussion}

In this study a total of 145 drinking water samples with different characteristics from all the zones of Tigray region, including the capital city of the region, Mekelle were analyzed for fecal contamination. The study indicated that $63(43.5 \%)$ of the water samples were detected to have fecal coliform. 
In Mekelle city, which is the capital of the region, three in five 34(60.7\%) of the collected samples were confirmed to have fecal coliform. Zone, setting/vicinity and facility of the water sample collected, type of source, Season of sample collection, reported water chlorination, and coliform count were the factors significantly associated with the presence of fecal coliform in the water samples.

Water samples from central zone were 38 times more likely to have fecal coliform than Water samples from Mekelle controlling for the other confounders. Among the six zones, the central zone is more populated and this may be the reason for the higher fecal contamination rates for drinking water sources from this area [20].

Health care facilities need an improved water sources for infection control and hygiene and they have higher demands for the activities like cleaning, laundry, and personal hygiene [21]. According a study by WHO, among 54 low-income countries, $42 \%$ of health care facilities have not improved water sources within 500 meter [22]. In our study the drinking water samples were from different facilities like public, health facilities and different organizations or universities and colleges. Among the water samples, those from health facilities were 9.48 times more likely to have fecal coliform than water samples from public sources. This may be due to the fact that, in low-income countries, even though there is a connection to piped water supply from an improved source, there is a high risk of contamination due to intermittent and substandard infrastructure [23-25].

Water samples from Towns were $98 \%$ [AOR $=0.02,95 \% \mathrm{Cl}:(0.00,0.35)]$ less likely to have fecal coliform than water samples from major city. This is in contrary with another study stating that water samples from towns are constructed very near or down latrines and are more likely for fecal contamination [26]. The reason for the higher fecal contamination rate in the main city may be due to shortage of continuous water supply and intermittent chlorination of drinking water in Mekelle city.

Water samples from wells were 10.23 times [AOR=10.23, 95\%Cl: $(2.74,38.26)]$ more likely to have fecal coliform than water samples from Tap/Pipe. Similarly, water samples from hand pumps were 22.28 times [AOR=22.28, 95\%Cl: $(1.26,393.7)]$ more likely to have fecal coliform than water samples from Tap/Pipe. This may be due to improper construction of casing, concrete covers, fences, diversion ditches and lack of regular supervision, disinfection and proper maintenance of the water sources from wells and hand pumbs $[27,28]$.

In our study, even though the water samples reported to be not chlorinated were 3.51 times [AOR=3.51, $95 \% \mathrm{Cl}:(1.35,9.13)]$ more likely to have fecal coliform than water samples from chlorinated sources (Table 3), the water sources which are chlorinated are also highly contaminated with fecal coliforms (31(34.1\%)). This could be due to intermittent and inadequate chlorination of the water sources [29-31].

The rainy season favored more for fecal contamination of drinking water as open defecation contributes to conversion of large areas into fecal fields which potentially put the village and water sources at risk of flooding with fecal materials [7]. This is shown in our study, in which water samples collected during the rainy season are more prone to fecal contamination than the counterpart.

Page $11 / 15$ 


\section{Conclusion}

In this study all water sources, including the chlorinated drinking water sources, were found highly contaminated with fecal origin bacteria. This may be mainly due to constructional defects, poor sanitation inspection, poor maintenance, intermittent water supply and irregular chlorination.

Based on our findings, we recommend a proper sanitary inspection, infrastructure of water and sanitary facilities, regular disinfection and maintenance of water sources, and regular bacteriological analysis of drinking water sources and putting immediate interventions based on findings of the bacteriological water analysis for all water sources intended for drinking and other domestic uses.

\section{List Of Abbreviations}

AOR: Adjusted Odds Ratio

Cl: Confidence Interval

E. coli: Escherichia coli

L-EMB: Levine Eosin Methylene Blue

MDGs: Millennium Development Goals

MPN: Most Probable Number

TTCs: Total Coli forms

UNICEF: United Nations Children's Fund

WASH: Water, Sanitation, and Hygiene

WHO: World Health Organization

\section{Declarations}

\section{Ethics approval and consent to participate}

All procedures performed in this study were in accordance with the ethical standards of the institutional and national research committee and with the 1964 Helsinki declaration and its later amendments or comparable ethical standards. Ethical clearance was obtained from Tigray health research institute institutional review team. Confidentiality of data and the scientific honesty during write up was considered.

Consent for publication 
The authors gave their consent for publication of this original research work.

\section{Availability of data and material}

The authors ensure the availability of data and material of this research work and are ready to provide when requested.

\section{Competing interests}

The authors declare no competing interests

\section{Funding}

This study was not funded by any party.

\section{Authors' contributions}

GG conceived the study idea, designed the analysis and write up of the manuscript. AB performed the data management and analysis and participated in the manuscript write up. AA and LL participated developing the manuscript and reviewing it for final submission. The authors agree to be accountable for all aspects of the work related to the accuracy or integrity of any part of the work, and have read and approved the manuscript.

\section{Acknowledgements}

The authors would acknowledge Tigray health research institute and the institutes from which the drinking water samples were collected, and the sample collectors.

\section{References}

1. WHO. Guidelines for Drinking-water Quality, Fourth edition. WHO, Geneva, Switzerland, 2011.

2. Daud MK, Nafees M, Ali S, et al. Drinking water quality status and contamination in Pakistan. Biomed Res Int 2017; 1-18. doi.org/10.1155/2017/7908183.

3. Levy K, Nelson KL, Hubbard A, Eisenberg JNS. Rethinking indicators of microbial drinking water quality for health studies in tropical developing countries: case study in Northern Coastal Ecuador. Am J Trop Med Hyg 2012; 86(3): 499-507. doi:10.4269/ajtmh.2012.11-0263

4. WHO. Water for health, WHO Guidelines for Drinking-water Quality, WHO Geneva, Switzerland 2010.

5. WHO/UNICEF. Rapid assessment drinking water quality in the Federal Democratic Republic of Ethiopia, Country Report of Pilot Project Implementation in 2004-2005. WHO, Geneva and UNICEF, New York, 2010. 
6. WHO/UNICEF. Progress on Drinking-Water and Sanitation: 2012 Update. WHO/UNICEF: Geneva, Switzerland 2012. Available: https://www.unicef.org/publications/index_69025.html (accessed 26 February 2019).

7. WHO/UNICEF. Progress on Sanitation and Drinking Water: 2015 Update and MDG Assessment; WHO: Geneva, Switzerland, 2015.

8. WHO/UNICEF. Progress on drinking water, sanitation, and hygiene: 2017 update and SDG baselines. Geneva: WHO Geneva, Switzerland 2017.

9. Cairncross S, Bartram J, Cumming O, Brocklehurst C. Hygiene, sanitation, and water: What needs to be done? PLoS Med 2010; 7(11):e1000365. doi: 10.1371/journal.pmed.1000365

10. Prüss-Üstün A, Bos R, Gore F, Bartram J. Safe Water, Better Health: Costs, Benefits and Sustainability of Interventions to Protect and Promote Health. WHO: Geneva, Switzerland, 2008.

11. Bowen $\mathrm{A}, \mathrm{Ma} \mathrm{H}, \mathrm{Ou} \mathrm{J}$ et al. A cluster-randomized controlled trial evaluating the effect of a handwashing-promotion program in Chinese primary schools. Am J Trop Med Hyg 2007; 76(6): 11661173.

12. Freeman MC, Greene LE, Dreibelbis $R$ et al. Assessing the impact of a school-based water treatment, hygiene and sanitation programme on pupil absence in Nyanza province, Kenya: a cluster-randomized trial. Trop Med Int Health 2012; 17(3): 380-391. doi: 10.1111/j.1365-3156.2011.02927.x. Epub 2011 Dec 18.

13. Garn JV, Greene LE, Dreibelbis R, Saboori S, Rheingans RD, Freeman MC. A cluster-randomized trial assessing the impact of school water, sanitation, and hygiene improvements on pupil enrollment and gender parity in enrollment. J Water Sanit Hyg Dev 2013; 3(4) doi: 10.2166/washdev.2013.217.

14. Prüss-Ustün A, Bonjour S, Corvalán C. The impact of the environment on health by country: A metasynthesis. Environ Health 2008; 7(7) doi: 10.1186/1476-069X-7-7

15. Siraj KT, Rao PP. Review on water resources and sources for safe drinking and improved sanitation in Ethiopia. Int J Appl Res 2016; 2(3): 78-82.

16. Ashbolt NJ, Grabow WO, Snozzi M. "Indicators of microbial quality," in Water Quality: Guidelines, Standards and Health: Assessment of risk and risk management for water-related infectious disease First Edition, Fewtrell L and Batrem J. WHO: Geneva, Switzerland 2001; 289-316.

17. Dufour A. "Escherichia coli: the fecal coliform," in Bacterial Indicators/Health Hazards Associated with Water, A. A. Hoadley, and B. J. Dutka (West Conshohocken, PA: ASTM International) 1977.

18. Ahmed T, Acharjee M, Rahman S et al. 2013. Microbiological study of drinking water: Qualitative and quantitative approach. Asian J Microbiol Biotech Env Sc 2013; 15 (4): 647-654. 
19. US Food and Drug Administration. Bacteriological analytical Manual 4: Enumeration of Escherichia coli and the Coliform Bacteria. Available online:

https://www.fda.gov/Food/FoodScienceResearch/LaboratoryMethods/ucm064948.htm (accessed on 1 March 2019)

20. Ahmed T, Baidya S, Acharjee M, Rahman T. Qualitative analysis of drinking water through the most probable number (MPN) method. S J Microbiol 2013; 3(1), 9-16.

21. Adams J, Bartram J, Chartier Y. Essential Environmental Health Standards in Health Care; WHO: Geneva, Switzerland, 2008. Available online:

http://www.who.int/water_sanitation_health/hygiene/settings/ehs_health_care.pdf.pdf (accessed on 26 February 2019).

22. Cronk R, Bartram J, Boisson S, Gordon B, Fewtrell L, Montgomery M. Water, Sanitation and Hygiene in Health Care Facilities: Status in Low and Middle Income Countries and Way Forward; WHO: Geneva, Switzerland, 2015. Available online:

http://apps.who.int/iris/bitstream/10665/154588/1/9789241508476_eng.pdf?ua=1 (accessed on 26 February 2019).

23. Lee EJ, Schwab KJ. Deficiencies in drinking water distribution systems in developing countries. J Water Health 2005; 3(2): 109-127.

24. Moe CL, Rheingans RD. Global challenges in water, sanitation and health. J. Water Health 2006, 4(1), 41-57.

25. Bain R, Cronk R, Wright J, Yang H, Slaymaker T, Bartram J. Fecal contamination of drinking-water in low- and middle-income countries: A systematic review and meta-analysis. PLOS Med. 2014; 11(5). doi:10.1371/journal.pmed.1001644.

26. WHO. International standards for drinking water, third edition, WHO: Geneva, Switzerland 1971.

27. Teka GE. Water supply-Ethiopia: an introduction to environmental health practice. AAU press, 1977.

28. Federal Democratic Republic of Ethiopia, MOH. Knowledge, attitude and practice of water supply, Environmental sanitation and hygiene practice in selected woredas of Ethiopia, 1997.

29. Craun GF, Brunkard JM, Yoder JS et al. Causes of Outbreaks Associated with Drinking Water in the United States from 1971 to 2006. Clin Microbiol Rev 2010; 23(3):507-528. doi: 10.1128/CMR.00077-09.

30. Kumpel E, Nelson KL. Comparing microbial water quality in an intermittent and continuous piped water supply. Water Res 2013; 47(14):5176-5188. doi: 10.1016/j.watres.2013.05.058.

31. Hrudey SE, Hrudey EJ, Pollard SJT. Risk management for assuring safe drinking water. Environ Int 2006; 32(8): 948-957. 